\title{
Hyperlipidemia, Tissue Factor, Coagulation and Simvastatin
}

\author{
A. Phillip Owens III, James Robert Byrnes, and Nigel Mackman \\ Department of Medicine, Division of Hematology and Oncology, McAllister Heart Institute, \\ University of North Carolina at Chapel Hill, Chapel Hill, NC 27599, USA
}

\begin{abstract}
Hyperlipidemia affects millions of people worldwide and is a major risk factor for cardiovascular disease. People with hyperlipidemia have elevated levels of serum cholesterol and an increased risk of thrombosis. Studies have suggested that oxidized lipoproteins, such as oxidized lowdensity lipoprotein (oxLDL), contribute to the development of a pro-thrombotic state. In this review, we discuss our recent studies demonstrating a role for hematopoietic cell-derived tissue factor (TF) expression in the activation of coagulation and increased thrombosis associated with hyperlipidemia. In addition, we investigated the effect of simvastatin on TF expression and coagulation. We found that simvastatin reduced leukocyte $\mathrm{TF}$ expression, $\mathrm{TF}^{+}$microparticles and coagulation. These results and earlier studies suggest that the anti-coagulant activity of statins is due, in part, to their ability to reduce monocyte TF expression in patients with cardiovascular disease.
\end{abstract}

\section{Introduction}

Lipids are transported in blood within lipoprotein particles. Hyperlipidemia describes a condition in which there are elevated levels of serum lipids. In the United States it is estimated that $\sim 33.5 \%$ of the adult population has elevated serum cholesterol levels ( $\geq 240$ $\mathrm{mg} / \mathrm{dL}$ ) (Go, Mozaffarian et al. 2013). Hyperlipidemia is a risk factor for the development of atherosclerosis because the excess lipids in the blood accumulate in the walls of arteries. Oxidation of low-density lipoprotein (LDL) results in the generation of oxidized (ox)LDL, which is a heterogeneous mixture of oxidized lipids and proteins (Levitan, Volkov et al. 2010). One bioactive oxidized lipid within oxLDL is oxidized 1-palmitoyl-2-arachidonoyl$s n$-glycero-3-phosphoryl-choline (oxPAPC). OxLDL binds a variety of cellular receptors on macrophages, monocytes, vascular smooth muscle cells (VSMCs) and endothelial cells (ECs). These receptors include the scavenger receptors SRAI/II, SRBI/II, CD36 and the immune receptor toll-like receptor 4 (TLR4) (Boullier, Bird et al. 2001, Kunjathoor, Febbraio et al. 2002). A recent study found that oxLDL activation of mouse macrophages and a human monocytic cell line called THP-1 is mediated by a CD36/TLR4/TLR6

() 2013 Elsevier Inc. All rights reserved.

Address for Correspondence: Nigel Mackman, PhD, University of North Carolina at Chapel Hill, Chapel Hill, North Carolina, Telephone: (919) 843 3961, Fax : (919) 966 7639, nmackman@med.unc.edu.

Publisher's Disclaimer: This is a PDF file of an unedited manuscript that has been accepted for publication. As a service to our customers we are providing this early version of the manuscript. The manuscript will undergo copyediting, typesetting, and review of the resulting proof before it is published in its final citable form. Please note that during the production process errors may be discovered which could affect the content, and all legal disclaimers that apply to the journal pertain. 
heterotrimeric receptor complex (Stewart, Stuart et al. 2010). OxLDL also increases TLR4 expression in macrophages, and hyperlipidemia is associated with increased TLR4 expression on circulating monocytes (Xu, Shah et al. 2001, Methe, Kim et al. 2005).

$\mathrm{TF}$ is a transmembrane receptor that binds factor VII/VIIa and activates the clotting cascade (Mackman 2009). It plays an essential role in hemostasis since inactivation of the TF gene in mice is associated with embryonic lethality. Exposure of monocytes to bacterial LPS induces TF expression (Mackman, Brand et al. 1991). It is thought that TF expression by monocytes is part of the host response to infection and helps prevent dissemination of the infection. However, monocyte TF expression can also contribute to thrombosis.

Hyperlipidemia is associated with a pro-thrombotic state (Eitzman, Westrick et al. 2000, Podrez, Byzova et al. 2007, Diaz, Ballard-Lipka et al. 2012). Recent studies have demonstrated that hyperlipidemia and oxLDL activates platelets via CD36 (Podrez, Byzova et al. 2007). Studies have demonstrated that circulating monocytes from hyperlipidemic individuals have higher levels of tissue factor (TF) compared with healthy controls (Ferro, Basili et al. 1997, Puccetti, Bruni et al. 2000). In addition, acute coronary syndrome patients have elevated levels of both circulating monocyte-derived microparticles (MPs) as well as $\mathrm{TF}^{+}$MPs (Matsumoto, Nomura et al. 2004, Morel, Pereira et al. 2009, Owens and Mackman 2011). MPs are small membrane vesicles released from activated and apoptotic cells and elevated levels are observed in the circulation in various pathological conditions (Owens and Mackman 2011). Finally, injection of oxidized lipids also increased TF expression in blood cells in mice (Kadl, Huber et al. 2002).

Rupture of atherosclerotic plaques induces the formation of intravascular thrombi that may occlude blood flow and lead to myocardial infarction and stroke. Atherosclerotic plaques contain high levels of TF (Wilcox, Smith et al. 1989). In addition, atherosclerotic plaques contain high levels of monocyte-derived $\mathrm{TF}^{+}$MPs (Leroyer, Isobe et al. 2007). Platelets are activated by the exposed collagen whereas the clotting cascade is activated by TF within the plaque (Owens and Mackman 2012). In vitro studies have shown that oxLDL induces TF expression in monocyte-derived macrophages, ECs and VSMCs (Drake, Hannani et al. 1991, Cui, Penn et al. 1999, Ross 1999, Levitan, Volkov et al. 2010, Meisel, Xu et al. 2011). Additionally, oxPAPC induces TF expression in human endothelial cells in a TLR2 and Egr-1-dependent manner (Bochkov, Mechtcheriakova et al. 2002).

The statin family of drugs is the most widely prescribed medication class in the world. Statins lower cholesterol levels in hyperlipidemic patients by inhibiting the rate limiting enzyme in cholesterol synthesis 3-hydroxy-3-methylglutaryl co-enzyme A reductase (HMGCoA reductase) that is present in the liver. However, statins also have additional activities independent of their lipid lowering activity, including anti-oxidant, anti-inflammatory, and anti-thrombotic activities (Di Garbo, Bono et al. 2000, Albert, Danielson et al. 2001, Liao and Laufs 2005). Statins also reduce TLR4 expression in human monocytes both in vitro and in vivo (Methe, Kim et al. 2005). Recent studies have found that statins also decrease venous thrombosis in a mouse model and in humans (Glynn, Danielson et al. 2009, Patterson, Zhang et al. 2013). 
Statins have been found to reduce TF expression in atherosclerotic plaques in hyperlipidemic mice, rabbits, pigs and monkeys without affecting lipid levels (Aikawa, Rabkin et al. 2001, Sukhova, Williams et al. 2002, Bea, Blessing et al. 2003, Casani, Sanchez-Gomez et al. 2005, Monetti, Canavesi et al. 2007). Moreover, simvastatin reduced monocyte TF expression in hypercholesterolemic patients (Ferro, Basili et al. 1997). In the Jupiter study the authors speculated that the decrease in venous thrombosis may be due to rosuvastatin inhibition of monocte TF expression. In vitro studies demonstrated that statins can directly inhibit inducible TF expression in various cells types, including monocytes and macrophages (Colli, Eligini et al. 1997, Ferro, Basili et al. 1997, Ferro, Basili et al. 2000, Aikawa, Rabkin et al. 2001).

This review will focus on our recent study examining the role of TF in the activation of coagulation in animal models of hyperlipidemia and the effect of administration of simvastatin (Owens, Passam et al. 2012).

\section{OxLDL induces TF expression in monocytic cells and human monocytes in vitro}

We found that oxLDL, but not LDL, increased TF expression in both human THP-1 monocytic cells and human monocytes (Owens, Passam et al. 2012). OxLDL also increased the number $\mathrm{TF}^{+} \mathrm{MPs}$ present in the culture medium. Inhibition of TLR4 reduced oxLDL induction of monocytic TF expression and $\mathrm{TF}^{+}$MPs (Owens, Passam et al. 2012). We are currently investigating the intracellular signaling pathways and transcription factors that mediate oxLDL induction of TF gene expression in monocytic cells. Next, we examined the effect of simvastatin on oxLDL induction of TF expression in THP-1 cells and human monocytes. Pretreatment of THP-1 cells and human monocytes with simvastatin significantly reduced oxLDL induction of both cellular and MP TF activity (Owens, Passam et al. 2012) (Figure 1). Previous studies have proposed that statins reduce TF expression by inhibiting geranylgeranyl pyrophosphate (GGPP)-dependent prenylation of Rho A (Eto, Kozai et al. 2002, Nagata, Ishibashi et al. 2002). An alternative possibility is that simvastatin activates the phosphatidylinositol Akt pathway that has been shown to negatively regulate LPS induction of TF gene expression in monocytic cells (Guha and Mackman 2002). We are currently investigating the mechanism by which simvastatin reduces oxLDL induction of TF gene expression in monocytic cells.

\section{Hyperlipidemic induction of leukocyteTF expression produces a prothrombotic state in animal models}

We hypothesized that the pro-thrombotic state associated with hyperlipidemia is due to oxLDL induction of monocyte TF expression (Owens, Passam et al. 2012). We measured levels of $\mathrm{TF}^{+} \mathrm{MPs}$ as a biomarker of monocyte activation. Consistent with our hypothesis, we found that patients with familial hyperlipidemia had an elevated level of circulating oxLDL and this correlated with levels of MP TF activity and activation of coagulation (Owens, Passam et al. 2012). A high fat diet led to time-dependent increases in plasma oxLDL, white blood cell TF activity, MP TF activity, and activation of coagulation in 
$\mathrm{LDLr}^{-/-}$mice and monkeys. Importantly, inhibition of $\mathrm{TF}$ in hyperlipidemic $\mathrm{LDLr}^{-/-}$mice reduced the activation of coagulation. Furthermore, hyperlipidemic $\mathrm{LDLr}^{-/-}$mice with a deficiency of TF in hematopoietic cells had significantly less MP TF activity and the activation of coagulation. We also found that $\mathrm{LDLr}^{-/}$mice deficient in either TLR4 or TLR6 had a significantly reduced level of MP TF activity and activation of coagulation compared with $\mathrm{LDLr}^{-/}$mice with wild-type levels of TLR4 and TLR6. Interestingly, hyperlipidemia also led to increased CD36, TLR4, and TLR6 mRNA expression in circulating monocytes (Owens, Passam et al. 2012). These results suggest that monocyte TF drives the activation of coagulation in hyperlipidemic animal models and in humans.

\section{Simvastatin, TF expression and activation of coagulation in hyperlipidemic animal models}

We examined the effect of administration of simvastatin to hyperlipidemic $\mathrm{LDLr}^{-/}$mice and monkeys on circulating TF expression and the activation of coagulation (Owens, Passam et al. 2012). Simvastatin reduced levels of oxLDL, leukocyte TF expression, MP TF activity, and the activation of coagulation without affecting lipid levels (Figure 1). Moreover, we also found that simvastatin reduced the inflammatory markers IL-6 and Creactive protein in hyperlipidemic $\mathrm{LDLr}^{-/}$mice and hypercholesterolemic monkeys, respectively. The observed reduction in oxLDL may be due to the inhibition of oxidative modification of LDL or enhanced clearance of the oxidized phospholipids (Rosenson 2004, Tsimikas, Witztum et al. 2004). We also found simvastatin reduced the expression of TLR4, TLR6, and CD36 mRNA in peripheral monocytes in hypercholesterolemic monkeys (Owens, Passam et al. 2012).

\section{Conclusions}

Hyperlipidemia produces a pro-thrombotic state in animal models by increasing TF expression on circulating monocytes and via the release of highly pro-coagulant $\mathrm{TF}^{+} \mathrm{MPs}$. This "circulating TF" may also contribute to the formation of an occlusive thrombus after plaque rupture. We propose that circulating $\mathrm{TF}^{+} \mathrm{MPs}$ may be a useful biomarker to identify patients that are at high risk for both arterial and venous thrombosis. In addition, they may be useful in monitoring the effectiveness of various interventional therapies, such as statin therapy, on reducing monocyte activation. More studies are needed to better understand how statins reduce the levels of oxLDL, the CD36/TLR4/TLR6 receptor complex and monocyte $\mathrm{TF}$ expression so that a new generation of anti-coagulant drugs can be developed for patients with hyperlipidemia. Targeting the inducible, pathologic TF expression without affecting the constitutive, hemostatic TF should be a safer strategy to reduce thrombosis in patients with cardiovascular disease.

\section{References}

Aikawa M, Rabkin E, Sugiyama S, Voglic SJ, Fukumoto Y, Furukawa Y, Shiomi M, Schoen FJ, Libby P. An HMG-CoA reductase inhibitor, cerivastatin, suppresses growth of macrophages expressing matrix metalloproteinases and tissue factor in vivo and in vitro. Circulation. 2001; 103(2):276-283. [PubMed: 11208689] 
Albert MA, Danielson E, Rifai N, Ridker PM, P. Investigators. Effect of statin therapy on C-reactive protein levels: the pravastatin inflammation/CRP evaluation (PRINCE): a randomized trial and cohort study. JAMA. 2001; 286(1):64-70. [PubMed: 11434828]

Bea F, Blessing E, Shelley MI, Shultz JM, Rosenfeld ME. Simvastatin inhibits expression of tissue factor in advanced atherosclerotic lesions of apolipoprotein $E$ deficient mice independently of lipid lowering: potential role of simvastatin-mediated inhibition of Egr-1 expression and activation. Atherosclerosis. 2003; 167:187-194. [PubMed: 12818400]

Bochkov VN, Mechtcheriakova D, Lucerna M, Huber J, Malli R, Graier WF, Hofer E, Binder BR, Leitinger N. Oxidized phospholipids stimulate tissue factor expression in human endothelial cells via activation of ERK/EGR-1 and $\mathrm{Ca}(++) / N F A T$. Blood. 2002; 99:199-206. [PubMed: 11756172]

Boullier A, Bird DA, Chang MK, Dennis EA, Friedman P, Gillotre-Taylor K, Horkko S, Palinski W, Quehenberger O, Shaw P, Steinberg D, Terpstra V, Witztum JL. Scavenger receptors, oxidized LDL, and atherosclerosis. Ann N Y Acad Sci. 2001; 947:214-222. discussion 222-213. [PubMed: 11795269]

Casani L, Sanchez-Gomez S, Vilahur G, Badimon L. Pravastatin reduces thrombogenicity by mechanisms beyond plasma cholesterol lowering. Thromb Haemost. 2005; 94(5):1035-1041. [PubMed: 16363247]

Colli S, Eligini S, Lalli M, Camera M, Paoletti R, Tremoli E. Vastatins inhibit tissue factor in cultured human macrophages. A novel mechanism of protection against atherothrombosis. Arterioscler Thromb Vasc Biol. 1997; 17:265-272. [PubMed: 9081680]

Cui MZ, Penn MS, Chisolm GM. Native and oxidized low density lipoprotein induction of tissue factor gene expression in smooth muscle cells is mediated by both Egr-1 and Sp1. J Biol Chem. 1999; 274(46):32795-32802. [PubMed: 10551840]

Di Garbo V, Bono M, Di Raimondo D, De Simone R, Raneli G, Avellone G. Non lipid, dosedependent effects of pravastatin treatment on hemostatic system and inflammatory response. Eur J Clin Pharmacol. 2000; 56(4):277-284. [PubMed: 10954339]

Diaz JA, Ballard-Lipka NE, Farris DM, Hawley AE, Wrobleski SK, Myers DD, Henke PK, Lawrence DA, Wakefield TW. Impaired fibrinolytic system in ApoE gene-deleted mice with hyperlipidemia augments deep vein thrombosis. J Vasc Surg. 2012; 55(3):815-822. [PubMed: 22119245]

Drake TA, Hannani K, Fei HH, Lavi S, Berliner JA. Minimally oxidized low-density lipoprotein induces tissue factor expression in cultured human endothelial cells. Am J Pathol. 1991; 138(3): 601-607. [PubMed: 2000938]

Eitzman DT, Westrick RJ, Xu Z, Tyson J, Ginsburg D. Hyperlipidemia promotes thrombosis after injury to atherosclerotic vessels in apolipoprotein E-deficient mice. Arterioscler Thromb Vasc Biol. 2000; 20(7):1831-1834. [PubMed: 10894825]

Eto M, Kozai T, Cosentino F, Joch H, Luscher TF. Statin prevents tissue factor expression in human endothelial cells: role of Rho/Rho-kinase and Akt pathways. Circulation. 2002; 105(15):17561759. [PubMed: 11956113]

Ferro D, Basili S, Alessandri C, Cara D, Violi F. Inhibition of tissue-factor-mediated thrombin generation by simvastatin. Atherosclerosis. 2000; 149:111-116. [PubMed: 10704621]

Ferro D, Basili S, Alessandri C, Mantovani B, Cordova C, Violi F. Simvastatin reduces monocytetissue-factor expression type IIa hypercholesterolemia. Lancet. 1997; 350:1222. [PubMed: 9652566]

Glynn RJ, Danielson E, Fonseca FA, Genest J, Gotto AM Jr, Kastelein JJ, Koenig W, Libby P, Lorenzatti AJ, MacFadyen JG, Nordestgaard BG, Shepherd J, Willerson JT, Ridker PM. A randomized trial of rosuvastatin in the prevention of venous thromboembolism. N Engl J Med. 2009; 360(18):1851-1861. [PubMed: 19329822]

Go AS, Mozaffarian D, Roger VL, Benjamin EJ, Berry JD, Borden WB, Bravata DM, Dai S, Ford ES, Fox CS, Franco S, Fullerton HJ, Gillespie C, Hailpern SM, Heit JA, Howard VJ, Huffman MD, Kissela BM, Kittner SJ, Lackland DT, Lichtman JH, Lisabeth LD, Magid D, Marcus GM, Marelli A, Matchar DB, McGuire DK, Mohler ER, Moy CS, Mussolino ME, Nichol G, Paynter NP, Schreiner PJ, Sorlie PD, Stein J, Turan TN, Virani SS, Wong ND, Woo D, Turner MB, o. b. o. t. A. H. A. S. C. a. S. S. Subcommittee. Heart Disease and Stroke Statistics-2013 Update: A Report From the American Heart Association. Circulation. 2013; 127:e6-e245. [PubMed: 23239837] 
Guha M, Mackman N. The phosphatidylinositol 3-kinase-Akt pathway limits lipopolysaccharide activation of signaling pathways and expression of inflammatory mediators in human monocytic cells. J Biol Chem. 2002; 277(35):32124-32132. [PubMed: 12052830]

Kadl A, Huber J, Gruber F, Bochkov VN, Binder BR, Leitinger N. Analysis of inflammatory gene induction by oxidized phospholipids in vivo by quantitative real-time RT-PCR in comparison with effects of LPS. Vascul Pharmacol. 2002; 38:219-227. [PubMed: 12449018]

Kunjathoor VV, Febbraio M, Podrez EA, Moore KJ, Andersson L, Koehn S, Rhee JS, Silverstein R, Hoff HF, Freeman MW. Scavenger receptors class A-I/II and CD36 are the principal receptors responsible for the uptake of modified low density lipoprotein leading to lipid loading in macrophages. J Biol Chem. 2002; 277(51):49982-49988. [PubMed: 12376530]

Leroyer AS, Isobe H, Leseche G, Castier Y, Wassef M, Mallat Z, Binder BR, Tedgui A, Boulanger CM. Cellular origins and thrombogenic activity of microparticles isolated from human atherosclerotic plaques. J Am Coll Cardiol. 2007; 49(7):772-777. [PubMed: 17306706]

Levitan I, Volkov S, Subbaiah PV. Oxidized LDL: diversity, patterns of recognition, and pathophysiology. Antioxid Redox Signal. 2010; 13:39-75. [PubMed: 19888833]

Liao JK, Laufs U. Pleiotropic effects of statins. Annu Rev Pharmacol Toxicol. 2005; 45:89-118. [PubMed: 15822172]

Mackman N. The many faces of tissue factor. J Thromb Haemost. 2009; 7(Suppl 1):136-139. [PubMed: 19630786]

Mackman N, Brand K, Edgington TS. Lipopolysaccharide-mediated transcriptional activation of the human tissue factor gene in THP-1 monocytic cells requires both activator protein 1 and nuclear factor kappa B binding sites. J Exp Med. 1991; 174(6):1517-1526. [PubMed: 1744583]

Matsumoto N, Nomura S, Kamihata H, Kimura Y, Iwasaka T. Increased level of oxidized LDLdependent monocyte-derived microparticles in acute coronary syndrome. Thromb Haemost. 2004; 91:146-154. [PubMed: 14691580]

Meisel SR, Xu X-P, Edgington TS, Cercek B, Ong J, Kaul S, Shah PK. Dose-dependent modulation of tissue factor protein and procoagulant activity in human monocyte-derived macrophages by oxidized low density lipoprotein. J Atheroscler Thromb. 2011; 18:596-603. [PubMed: 21467727]

Methe H, Kim J-O, Kofler S, Nabauer M, Weis M. Statins decrease Toll-like receptor 4 expression and downstream signaling in human CD14+ monocytes. Arterioscler Thromb Vasc Biol. 2005; 25:1439-1445. [PubMed: 15860745]

Methe H, Kim J-O, Kofler S, Weis M, Nabauer M, Koglin J. Expansion of circulating Toll-like receptor 4-positive monocytes in patients with acute coronary syndrome. Circulation. 2005; 111:2654-2661. [PubMed: 15883205]

Monetti M, Canavesi M, Camera M, Parente R, Paoletti R, Tremoli E, Corsini A, Bellosta S. Rosuvastatin displays anti-atherothrombotic and anti-inflammatory properties in apoE-deficient mice. Pharmacological Research. 2007; 55:441-449. [PubMed: 17350858]

Morel O, Pereira B, Averous G, Faure A, Jesel L, Germain P, Grunebaum L, Ohlmann P, Freyssinet J$\mathrm{M}$, Bareiss $\mathrm{P}$, Toti F. Increased levels of procoagulant tissue factor-bearing microparticles within the occluded coronary artery of patients with ST-segment elevation myocardial infarction: role of endothelial damage and leukocyte activation. Atherosclerosis. 2009; 204:636-641. [PubMed: 19091315]

Nagata K, Ishibashi T, Sakamoto T, Ohkawara H, Shindo J, Yokoyama K, Sugimoto K, Sakurada S, Takuwa Y, Nakamura S, Teramoto T, Maruyama Y. Rho/Rho-kinase is involved in the synthesis of tissue factor in human monocytes. Atherosclerosis. 2002; 163(1):39-47. [PubMed: 12048120]

Owens AP, Mackman N. Microparticles in hemostasis and thrombosis. Circ Res. 2011; 108:12841297. [PubMed: 21566224]

Owens AP, Mackman N. Role of tissue factor in atherothrombosis. Curr Atheroscler Rep. 2012; 14:394-401. [PubMed: 22886473]

Owens AP, Passam FH, Antoniak S, Marshall SM, McDaniel AL, Rudel L, Williams JC, Hubbard BK, Dutton J-A, Wang J, Tobias PS, Curtiss LK, Daugherty A, Kirchhofer D, Luyendyk JP, Moriarty PM, Nagarajan S, Furie BC, Furie B, Johns DG, Temel RE, Mackman N. Monocyte tissue factordependent activation of coagulation in hypercholesterolemic mice and monkeys is inhibited by simvastatin. J Clin Invest. 2012; 122:558-568. [PubMed: 22214850] 
Patterson KA, Zhang X, Wrobleski SK, Hawley AE, Lawrence DA, Wakefield TW, Myers DD, Diaz JA. Rosuvastatin reduced deep vein thrombosis in ApoE gene deleted mice with hyperlipidemia through non-lipid lowering effects. Thromb Res. 2013; 131(3):268-276. [PubMed: 23276528]

Podrez EA, Byzova TV, Febbraio M, Salomon RG, Ma Y, Valiyaveettil M, Poliakov E, Sun M, Finton PJ, Curtis BR, Chen J, Zhang R, Silverstein RL, Hazen SL. Platelet CD36 links hyperlipidemia, oxidant stress and a prothrombotic phenotype. Nat Med. 2007; 13(9):1086-1095. [PubMed: 17721545]

Puccetti L, Bruni F, Bova G, Cercignani M, Pompella G, Auteri A, Pasqui AL. Role of platelets in tissue factor expression by monocytes in normal and hypercholesterolemic subjects. In vitro effect of cerivastatin. Int J Clin Lab Res. 2000; 30:147-156. [PubMed: 11196073]

Rosenson RS. Statins in atherosclerosis: lipid-lowering agents with antioxidant capabilities. Atherosclerosis. 2004; 173(1):1-12. [PubMed: 15177118]

Ross R. Atherosclerosis-an inflammatory disease. N Engl J Med. 1999; 340:115-126. [PubMed: 9887164]

Stewart CR, Stuart LM, Wilkinson K, van Gils JM, Deng J, Halle A, Rayner KJ, Boyer L, Zhong R, Frazier WA, Lacy-Hulbert A, El Khoury J, Golenbock DT, Moore KJ. CD36 ligands promote sterile inflammation through assembly of a Toll-like receptor 4 and 6 heterodimer. Nat Immunol. 2010; 11:155-161. [PubMed: 20037584]

Sukhova GK, Williams JK, Libby P. Statins reduce inflammation in atheroma of nonhuman primates independent of effects on serum cholesterol. Arterioscler Thromb Vasc Biol. 2002; 22(9):14521458. [PubMed: 12231565]

Tsimikas S, Witztum JL, Miller ER, Sasiela WJ, Szarek M, Olsson AG, Schwartz GG, I. Myocardial Ischemia Reduction with Aggressive Cholesterol Lowering Study. High-dose atorvastatin reduces total plasma levels of oxidized phospholipids and immune complexes present on apolipoprotein B-100 in patients with acute coronary syndromes in the MIRACL trial. Circulation. 2004; 110(11): 1406-1412. [PubMed: 15353498]

Wilcox JN, Smith KM, Schwartz SM, Gordon D. Localization of tissue factor in the normal vessel wall and in the atherosclerotic plaque. Proc Natl Acad Sci U S A. 1989; 86(8):2839-2843. [PubMed: 2704749]

Xu XH, Shah PK, Faure E, Equils O, Thomas L, Fishbein MC, Luthringer D, Xu XP, Rajavashisth TB, Yano J, Kaul S, Arditi M. Toll-like receptor-4 is expressed by macrophages in murine and human lipid-rich atherosclerotic plaques and upregulated by oxidized LDL. Circulation. 2001; 104:31033108. [PubMed: 11748108] 


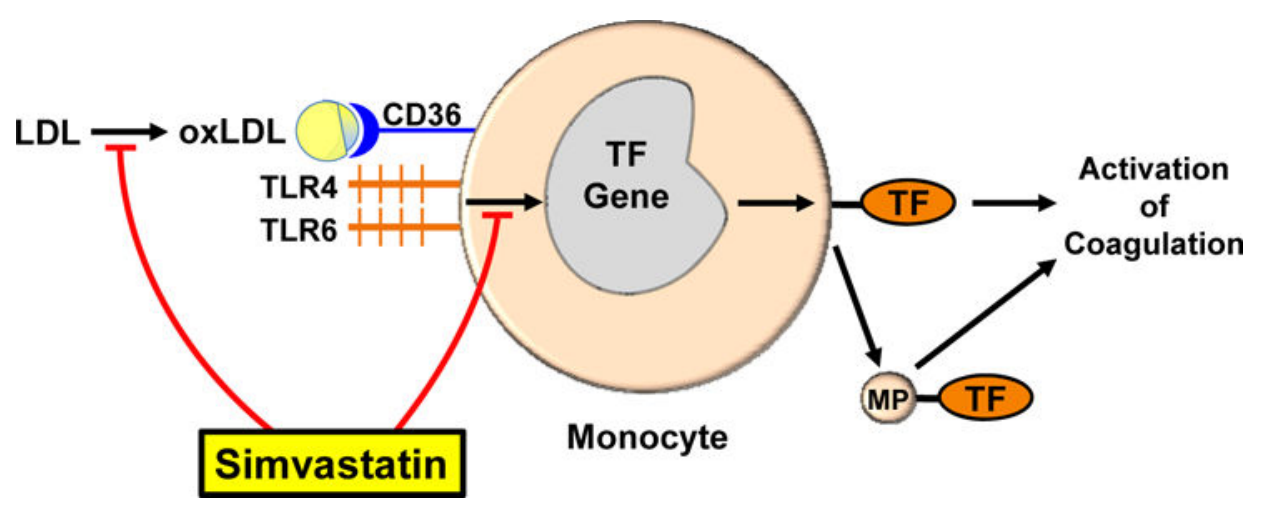

Figure 1.

Proposed sites of simvastatin inhibition of monocytic TF expression. LDL is converted to oxLDL which binds to a CD36/TLR4/TLR6 heterotrimeric complex on the surface of circulating monocyte that activates various intracellular signaling pathways and transcription factors required for TF gene expression. This results in increased TF protein expression on the surface of the monocyte, increased CD36/TLR4/TLR6 expression, and release of $\mathrm{TF}^{+}$ MPs. Simvastatin reduces the levels of oxLDL, levels of the CD36/TLR4/TLR6 complex and TF expression. 